\title{
Implementation of the motivation and incentive models of employees of the LLC "Rucheek" of Krasnodar Territory
}

\author{
Victor V. Moiseev, and Arkady V. Moiseev* \\ Kuban State Agrarian University named after I.T.Trubilin, Krasnodar, Russia
}

\begin{abstract}
The article discusses and analyzes the implementation of models of motivation and incentives of employees of the company that produces mineral water. Modern methods and tools of employee management at the enterprise are studied. Analysis of the system of motivation and incentive of the organization's personnel allows us to justify the feasibility of recommendations for improving the motivation system in the LLC "Rucheek". The degree of implementation recommendations of proposals for improving the system of personnel motivation, is justified. As a result of this work, we received proposals for improving motivation systems at the enterprise. The models used will significantly increase the economic efficiency of the organization.
\end{abstract}

In modern economic conditions, the problem of motivation and incentives for employees has become one of the most discussed in the economic literature. With all the variety of forms and methods of increasing staff motivation, the problem of choosing the optimal incentive and remuneration model does not lose its relevance. Despite the uniqueness of each organization, there are some regularities that are taken into account in the practice of creation of motivation and incentive systems to help ensure the greatest return. Today, businesses are given the right to develop and implement motivational systems independently, the effectiveness of which is largely determined by the principles of their creation. It is possible to increase production efficiency and achieve competitiveness faster if you use a rich scientific experience [1].

Staff incentives are always complementary to the organization's motivational policy; they are a means of meeting the specific needs of employees, mainly material ones.

Motivation and stimulation as methods of labor management are opposite in orientation: the first is aimed at changing the existing situation; the second - at fixing it, but they are mutually complementary.

In the literature, you can see a variety of classifications of methods, a generally accepted one is their division into administrative, economic, socio-psychological.

Administrative methods are characterized by their compliance with legal norms and are based on power, penalties and discipline [2].

Economic methods of management are a set of ways to influence the economic interests of the object of management, based on the conscious use of the requirements of economic

\footnotetext{
*Corresponding author: moiseew_a@rambler.ru
} 
laws.

Socio-psychological methods are aimed at managing socio-psychological processes in the team to achieve this goal, provided that the protection of health of employees and a good moral and psychological climate in the team, compliance with legislation and requirements, regulations.

We have considered, analyzed and assessed the management of the personnel of the LLC "Rucheek". The LLC "Rucheek" has been the largest enterprise in Krasnodar Territory which is engaged in bottling of mineral and potable water "Goryachiy Klyuch" and soft drinks since 1998. Water bottling is very relevant at present time, this process is very widespr ead and monetized. According to the results of the analysis of financial activity, the company is profitable. But, in 2019, there is a decline, compared to 2018. Due to the fact, 2019 was a crisis year for the company [3].

To date, the number of staff units is 128 people.

The company's management structure is linear and functional. One specialist is responsible for performing tasks in the field of personnel management. More than $60 \%$ of employees are engaged in production.

The staff turnover rate increases to $14.29 \%$ in 2019 , which is a negative indicator.

About $40 \%$ of employees are between 30 and 40 years old. Most of them occupy the highest level of management. As a result, we can note the traditional distribution of personnel, in which at the highest level of management there are employees of middle, socially active age, who have both physical and intellectual opportunities for active work. $56 \%$ of employees have higher education - it has a positive effect on the overall operation of the company. More than $50 \%$ of employees have been working at this company for more than 10 years [4].

According to the Labor Code of the Russian Federation, the company has developed local regulatory documents. The company has all the functions of personnel management, except for planning.

The LLC "Rucheek" has developed stimulation methods that are reflected in the collective agreement. The material and non-material system of personnel motivation is applied. Analysis of the system of incentives and motivation of the company's personnel showed that the system was reasonable and quite effective. Shortcomings in the way of motivation were revealed as a result of the analysis [5].

For more efficient improvement of the system of motivation it is necessary to use the existing positive moments in the LLC "Rucheek" in maximum and try to eliminate factors causing most dissatisfaction among employees in the quickest way employees who showed low satisfaction with the size of wages and the ratio of work to salary, considering that the principle of fair salary in the LLC "Rucheek" is not fulfilled. It often leads to conflicts between employees. In this chapter, I have suggested the ways to improve and assess the expected effect of implementing the recommendations [6].

To improve the use of organizational and administrative methods in the organization, it is proposed:

- develop a state of career;

- develop regulations on bonuses;

- develop a new regulation on remuneration and make changes to the job descriptions of the appropriate level of management.

To improve the socio-psychological methods of staff motivation:

- develop a conflict management system (conducting psychological trainings 2 times a year and engaging a psychologist 1 time a year);

- develop organizational culture (regular meetings, observance of traditions); 
- implement a system of emotional monitoring (SEM) of personnel.

The costs of implementing social and psychological methods were 12,000 rubles. To improve economic methods:

- install the GLONASS system;

- enter a score system.

The costs of implementing economic methods were 102,880 rubles.

The analysis of this table shows that the net profit of the LLC "Rucheek" in the implementation of proposals will amount to 37,058 thousand rubles, i.e. will increase by $3.9 \%$. Next, we will analyze the economic efficiency of motivational costs. To do this, take the calculated net profit in the forecast compared to the results of 2019 under the influence of the proposed incentive programs for personnel (table 1).

Table 1. Calculation of economic efficiency of motivational expenses.

\begin{tabular}{|l|l|c|}
\hline \multicolumn{1}{|c|}{ Parameter } & \multicolumn{1}{c|}{ Formula } & Project, rub. \\
\hline Net profit fact $\left(\mathrm{NP}_{0}\right)$ & - & 35651000 \\
\hline Net profit project $\left(\mathrm{NP}_{1}\right)$ & - & 37058000 \\
\hline Net profit increase $(\Delta \mathrm{NP})$ & $\Delta \mathrm{NP}=\mathrm{NP}_{1}-\mathrm{NP}_{0}$ & 1407000 \\
\hline Motivational cost budget $\left(\mathrm{B}_{\mathrm{mc}}\right)$ & - & 114880 \\
\hline Net profit after deduction of motivational costs & $\mathrm{NP}_{1}-\mathrm{B}_{\mathrm{mc}}$ & 36943120 \\
\hline Net profit per 1 rub of of motivational costs & $\mathrm{NP}_{1} / \mathrm{B}_{\mathrm{mc}}$ & 323 \\
\hline $\begin{array}{l}\text { Increase in net profit per 1 rub of motivational } \\
\text { costs }\end{array}$ & $\Delta \mathrm{NP} / \mathrm{B}_{\mathrm{mc}}$ & 12,2 \\
\hline
\end{tabular}

From the analysis of the table, we can conclude that the increase in net profit in the forecast will be 1,407,000 rubles, the amount of net profit per 1 ruble of motivational costs is 323, and the increase in net profit per 1 ruble of motivational costs will be 12.2.

Thus, the evaluation of the economic efficiency of the developed incentive measures showed that it meets the "interests" of both the owner and the employees themselves on the one hand, it meets the needs of the company, on the other - the employees [7].

The forecast of parameters after improvement of motivation systems at the enterprise shows that the net profit of the LLC "Rucheek" in the implementation of proposals will amount to 37,058 thousand rubles, i.e. will increase by 3.9\%.

From the analysis of the calculation of the economic efficiency of motivational costs, we can conclude that the increase in net profit in the forecast will be 1,407 thousand rubles, the amount of net profit per 1 ruble of motivational costs is 323, and the increase in net profit per 1 ruble of motivational costs will be 12.2.

This project of measures to improve the methods of personnel management of the LLC "Rucheek" was developed on the basis of a thorough analysis of the personnel management system, in particular, the study of administrative, economic and socio-psychological ways to influence the employees of the enterprise's workforce.

The implementation of this project of measures is intended to ensure the expansion of the applied working methods with staff, and as a result, increase labor productivity. 


\section{References}

1. Berezhnaya O.V., Savtsova A.V., Berezhnaya E.V., Polivina M.A., Moiseev A.V. Evaluation methods of regional transport systems performance efficiency/ Journal of Internet Banking and Commerce. 2016. V. 21. № 6.

2. Moiseev V.V., Moiseev A.V. Improvement of innovation and investment management of confectionery enterprises of Krasnodar Territory. Fundamental researches. 2019. № 9. P. 44-48.

3. Saenko I.I., Tubalets A.A. Formation and management of the cluster strategy of the regional development of the agro-industrial complex of Krasnodar Territory. Naturalhumanitarian researches. 2020. No. 27 (1). P. 181-186.

4. Sandulova E. V., Cherepakhin T. Yu. The improved utilization of production resources of the enterprise. In the collection: Scientific support of agro industrial complex, Proceedings of 73rd of scientific-practical conference of students according to the results of researches in 2017. Chief editor A. G. Koshchaev. 2018. P. 890-893.

5. Trubilin A. I., Sidorenko V. V., Melnikov A. B., Mikhailushkin P. V. Price policy in the agricultural sector of the economy. International agricultural journal. 2019. No. 1 (367). P. 8-11.

6. Tyupakov K. E., Belova L. A., Vertiy M. V., Kurnosov V. S. Improvement of investment policy in the agro-industrial complex as a condition of ensuring economic security of the state. Economy, labor, management in agriculture. 2019. No. 11 (56). P. 104-112.

7. Chaika V. P., Papakhchyan I. A., Tolmachev A.V., Dyakov S. A. Directions of state support of regional agricultural production. In the book: National models of economic systems Arutyunov E. K., Harutyunyan Yu. I., Belova L. A., Berezovsky E. E., Bondareva D. E., etc. Collective monograph (Scientific publication). Krasnodar, 2019. P. 282-297. 